\title{
A Comparative analysis of global competences within the framework of internationalized curricula
}

\author{
Pablo Beneitone and Maria Yarosh*
}

doi: http://dx.doi.org/10.18543/tjhe-8(2)-2021pp25-53

Received: 31 March 2021

Accepted: 6 May 2021

\begin{abstract}
An agreement seems to exist that graduates must be equipped with competences required to act successfully and appropriately in a global context. Many authors have proposed lists of competences that could form part of such a graduate profile which must be taken into account when designing internationalized curricula. However, merely listing of a competence does not guarantee that students develop it to the level expected by society. The present article reports on a meta-study based on eight Tuning studies. This meta-study compared the findings across the eight Tuning studies in terms of the different stakeholder groups' ratings of importance and achievement of 11 global competences - generic competences valued by over 71,000 graduates, employers, students and academics in more than 100 countries and across four continents (Europe, Latin America, Africa and Asia). The contribution of the meta-study presented consists in offering a possibility to identify commonalities and differences among the perceptions of the four key stakeholder groups, not only across all the individual studies but also at the level of the four continents - something never accomplished until the present date. In addition, it will help identify the competences that might require particular attention of curriculum designers and teaching teams for students to develop these competences to the level perceived as optimal in
\end{abstract}

* Dr. Pablo Beneitone (pbeneitone@unla.edu.ar), PhD in Social Sciences, is Professor at the National University of Lanús (Argentina) where he is the director of research on academic mobility, credit systems, global competences, and learning outcomes.

* Dr. Maria Yarosh (m.yarosh@rug.nl), PhD in Education, works at the International Tuning Academy at the University of Groningen, the Netherlands, as a researcher and faculty developer.

More information about the authors is available at the end of this article.

Disclosure statement: No potential conflict of interest was reported by the authors. 
different regions of the world. Future research questions are identified with the aim to enrich and validate or fine-tune these initial findings and compensate for the limitations related to the general timeline of the 8 individual Tuning studies that the meta-study built on.

Keywords: Academics; achievement; Africa; Asia; EAHEA; employers; Europe; generic competences; global competences; graduates; importance; internationalization of curriculum; Latin America; students.

\section{Introduction}

The development of graduates as global citizens is now claimed in the policies of many universities, ${ }^{1,2}$ but such an education for global citizenship demands a holistic redesign of degree programmes. ${ }^{3}$ Curriculum design - at least in a competence-based, student-centred paradigm - involves a series of decisions about what a graduate should be able to know, do, and be. Accordingly, thinking about future graduates implies considering the local needs and the national context where the degrees are conceived, but also accepting that the University is responsible for preparing future citizens and professionals who will live and work in a global environment. ${ }^{4}$ They must also ensure students develop desired competences to the necessary level, regardless of the mode of the programme delivery, and of whether international mobility can be undertaken by students or not.

As previous research shows, this broad aim has by now become part of the of discourse, but a number of questions require further exploration and work before this goal can become reality and university 2015)

${ }^{1}$ Betty Leask, Internationalizing the Curriculum (New York and London: Routledge,

${ }^{2}$ Valerie Clifford and Martin Haigh, "Graduate attributes for global citizenship," in Moving towards internationalisation of the curriculum for global citizenship in higher education, ed. Valerie Clifford and Catherine Montgomery (Oxford: OCSLD, Oxford Brookes University, 2011), 93-118.

3 Valerie Clifford and Catherine Montgomery, "Designing an internationationalised curriculum for higher education: embracing the local and the global citizen," Higher Education Research \& Development, 36 no. 6 (2017): 1138-1151, https://doi.org/10.1080/07294360.201 7.1296413 .

${ }^{4}$ Kathleen Lilley, Michelle Barker and Neil Harris, "Educating global citizens: a good 'idea' or an organisational practice?, Higher Education Research \& Development 34, no. 5 (2015): 957-971, doi: 10.1080/07294360.2015.1011089. 
curricula will, indeed, permit students to develop the necessary competences..$^{5,6,7,8}$

Two concrete obstacles that both scholars and practitioners of higher education (HE) must overcome are, firstly, a lack of consensus on competences that will make graduates ready for life and work in a globalized world, and secondly, a lack of data on how well the existing programmes are featuring in this respect. In relation to the first aspect, it appears promising that at least some of the recent studies show that there is a considerable overlap between the competences identified as important for (local) employers and those that have been identified as necessary to become global citizens. ${ }^{9,10,11}$ On the other hand, Schech, Kelton, Carati and Kingsmill raise a highly relevant question of the extent to which a certain configuration of competences identified as desirable for all graduates in one part of the world can indeed compare to what graduates might need if they happen to work outside their country or continent. ${ }^{12}$ Borkovic, Nicolacopoulos, Horey and Fortune, in turn, call for further research on the success of current programmes in helping students develop such competences, research that can give concrete guidance, for example, about which of the competences should be addressed in more detail. ${ }^{13}$ Additionally, Sarkar, Overton, Thompson and Rayner suggest that

${ }^{5}$ Shinead Borkovic, Toula Nicolacopouloa, Dell Horey and Tracy Fortune, "Students positioned as global citizens in Australian and New Zealand universities: A discourse analysis," Higher Education Research \& Development 39, no. 6 (2020): 1106-1121. https:// doi: 10.1080/07294360.2020.1712677.

${ }^{6}$ Robert Wagenaar, Reform! TUNING the Modernisation Process of Higher Education in Europe. A Blueprint for Student-Centred Learning (Bilbao and Groningen, 2019).

7 Lilley, Barker and Harris, "Educating global citizens", 957-971.

${ }^{8}$ Sussane Schech, Maryanne Kelton, Colin Carati, and Verity Kingsmill, "Simulating the global workplace for graduate employability," Higher Education Research \& Development 36 , no. 7 (2017): 1476-1489. doi: 10.1080/07294360.2017.1325856.

9 Beverly Oliver and Trina Jorre de St Jorre, "Graduate attributes for 2020 and beyond: recommendations for Australian higher education providers," Higher Education Research \& Development 37, no. 4 (2018): 821-836. doi: 10.1080/07294360.2018.1446415.

10 Stefan Hajkowicz, Andrew Reeson, Lachlan Rudd, Alexandra Bratanova, Leonie Hodgers, Claire Mason and Naomi Boughen, Tomorrow's digitally enabled workforce: Megatrends and scenarios for jobs and employment in Australia over the coming twenty years (Brisbane: CSIRO, 2016).

${ }_{11}$ James Arvanitakis and David Hornsby, Universities, the citizen scholar and the future of higher education (Basingstoke: Palgrave Macmillan, 2016).

${ }_{12}$ Schech, Kelton, Carati and Kingsmill, "Simulating the global workplace", 1476-1489.

13 Borkovic, Nicolacopouloa, Horey and Fortune, "Students positioned as global citizens", 1106-1121. 
academics' perspectives might have not been prominent enough and that their opinions should be studied and given no lesser attention than the views of students, graduates and employers. ${ }^{14}$

Since the beginning of the $21^{\text {st }}$ century, academics from over a hundred countries - through eight independent but interrelated Tuning studies ${ }^{15,16,17,18,19,20,21,22}$ - have been involved in a debate with a focus on what competences should be aimed at in order to prepare students to work and life in the increasingly culturally-complex world, regardless of the students' future professional occupation. This article undertakes a detailed analysis of 11 competences which appeared in all the eight Tuning studies and might, therefore, be considered global. There are two main research questions behind this article:

- How relevant these 11 global competences are for different stakeholders in a diverse and large number of countries;

${ }^{14}$ Mahbub Sarkar, Tina Overton, Christopher D. Thompson, C. and Gerry Rayner, "Academics' perspectives of the teaching and development of generic employability skills in science curricula," Higher Education Research \& Development 39, no. 2 (2020): 346-361. doi: 10.1080/07294360.2019.1664998

${ }^{15}$ Pablo Beneitone and Edurne Bartolomé, "Global generic competences with local ownership: a comparative study from the perspective of graduates in four world regions," Tuning Journal for Higher Education 1, no. 2 (May 2014): 303-334. https://doi.org/10.18543/ tjhe-1(2)-2014.

16 Artur Demchuk, Ivan Dyukarev, Evgeniya Karavaeva, Pablo Beneitone, Julia González and Robert Wagenaar, Towards Comparability of Higher Education Programmes. Information Review (Bilbao: University of Deusto, 2013).

${ }_{17}$ Pablo Beneitone, César Esquetini, Julia González, Maida Marty Maleta, Gabriela Siufi and Robert Wagenaar, Reflections on and Outlook for Higher Education in Latin America (Bilbao: University of Deusto, 2007).

${ }^{18}$ Charles Awono Onana, Olusola Bandele Oyewole, Damtew Teferra, Pablo Beneitone, Julia González and Robert Wagenaar, Tuning and Harmonisation of Higher Education: The African Experience (Bilbao: University of Deusto, 2014).

19 Anne Katherine Isaacs, Ahahdon Najmitdinov and Aimen Tasbolat. TUCAHEA Tuning Central Asia Towards a Central Asian Higher Education Area. Pisa: Dedalo edizione, 2016.

${ }^{20}$ Robert Wagenaar, Arlene Gilpin and Pablo Beneitone, Tuning in China. An EU-China Feasibility Study into the Modernisation of Higher Education (Bilbao: Universidad de Deusto, 2015).

${ }^{21}$ Richard Jugar and Ouda Teda Ena, Reference Points for the Design and Delivery of Degree Programmes in Teacher Education. Tuning South East Asia (Bilbao: University of Deusto, 2019).

${ }^{22}$ Tuning India Project 2018. Accessed 17 October 2020. https://tuningindia.org/wpcontent/uploads/T-India-2GM-Booklet-web.pdf. 
- How well today's HE programmes - in different parts of the world and from the point of view of different stakeholders - are catering for the actual development of these 11 global competences (actual achievement versus perceived need to focus on these competences), and, thus, allowing graduates to effectively become global citizens and professionals.

With this, the authors seek to contribute to the discussion about which competences might need to be prioritized and paid more attention to by HE institutions in order to achieve curriculum internationalization. Furthermore, they should prepare graduates to perform globally, especially in the "postCovid world', where physical international mobility and extra-curricular activities cannot be taken for granted and expected to 'compensate' for lack of curricular attention to key non-subject-specific elements of desired graduate profiles.

\section{Methodology of the meta-study}

The present article analyses the data collected in eight Tuning studies across four continents between 2005 and 2018 (see Table 1 for an overview of the study scopes and samples). These studies were undertaken by academics from public and private universities who worked together in international curriculum development projects and sought, among other goals, to identify those generic competences (GCs) that were most valued by academics, graduates, students and employers of a particular region and those GCs which were in need of greater attention in HE programmes offered in the region in question. The focus was on identifying competences that any graduate in the region needs in order to be prepared to work and live in a culturally-diverse and changing world. Named 'generic competences', these were seen as complementary to those (subject-specific) competences that prepare students to join the chosen professional community; GCs were perceive as relevant for all students and graduates, regardless of the specialization/particular HE programme pursued.

Each study had a different geographical scope, but used the same methodology for initial identification of such competences, and consulting stakeholders on perceived importance and perceived achievement of each competence. 
All in all, 432 public and private universities were involved in these Tuning studies, and conducted consultations with stakeholders to collect data. Care was taken to bring together respondents from different education and occupation sectors so as to also represent multiple disciplinary perspectives. Participating universities were in charge of selecting different stakeholders in a random sample $(71,000$ respondents in total), provided that the following criteria were met:

- academics were to teach at each university participating in the study $(17,023$ in total),

- employers were to come from among those identified as usually hiring or likely to hire graduates of each university participating in the study $(9,387$ in total $)$

- students were to be enrolled in one of the last years of a degree programme offered by each participating university in the study $(26,207$ in total)

- graduates were to come from those who successfully completed a degree programme offered by each participating university, within five years before the date of the consultation $(18,477$ in total).

Students, graduates and academics had to come from the same programmes selected to represent viewpoints of different academic disciplines/sectors. Employers invited were those known or likely to hire graduates of the same programmes.

Stakeholders were consulted, with the use of an online questionnaire, about importance and perceived achievement of the GCs from a list agreed upon by inter-institutional and inter-disciplinary teams of academics who formed the core group of each Tuning study. Each respondent was required to:

a) indicate the importance of each of the competences in the list for ensuring that graduates could join and successfully navigate the world of employment and play the role expected of persons with HE degree in society. The same 4-point scale was used in all of the studies to rate the importance of the competences in the list (4-strong, 3 - considerable, 2 - weak, 1 - none).

b) indicate the extent to which he/she perceived each of the competences to be achieved by students enrolled in currently existing degree programmes by the end of the (first-cycle) HE degree programmes; again, the same 4-point scale was used in all the studies (4 - strong, 3 - considerable, 2 - weak, 1 - none). 
The meta-study compared the findings across the eight Tuning studies in terms of the different stakeholder groups' ratings of importance and achievement of 11 GCs. Those that were identified as key in all the studies could, therefore, be considered global competences:

1. Ability to apply knowledge in practice

2. Creativity

3. Problem solving

4. Critical and self-critical abilities

5. Capacity for abstract thinking, analysis and synthesis

6. Capacity to learn actively

7. Teamwork

8. Commitment to the conservation of the environment

9. Social responsibility and civic awareness

10. Oral and written communication

11. Appreciation of and respect for diversity and multiculturality

The meta-study presented in this article compared the different stakeholders' perspectives at two levels: the level of individual Tuning studies (8) and the level of the regions (4), grouping the eight studies according to the continent where they were conducted. The following four regions were distinguished:

- European Higher Education Area (EHEA) - Europe 2008 and Russia 2011 studies;

- Latin America - Latin America 2005/2012 study;

- Africa - Africa 2012/2015 study; and

- Asia - Central Asia 2013, China 2015, South-East Asia 2017 and India 2018 studies.

The eight studies and their findings are comparable for three key reasons. Firstly, they all worked with the same operational definition of the concept of (generic) competences. Secondly, the questionnaires administered in the eight studies - during the consultations - collected data about the same variables and using the same scale across all regions. Thirdly, the same four respondent groups were consulted in every study and these groups were defined in the same way. One of the main differences is the way in which the different regions and stakeholders weight these competences in curriculum, and the next section shares the findings of such meta-study, competence by competence. 


\section{Table 1}

Overview of the eight Tuning studies in terms of their geographical scope and the samples

\begin{tabular}{|c|c|c|c|c|c|c|}
\hline \multirow[t]{2}{*}{ Region } & \multirow[t]{2}{*}{ Study } & \multicolumn{5}{|c|}{$\begin{array}{l}\text { Number of respondents } \\
\text { (Academics - AA; Employers - EE; } \\
\text { Students - SS; Graduates - GG) }\end{array}$} \\
\hline & & AA & $\mathrm{EE}$ & SS & GG & Total \\
\hline \multirow{2}{*}{$\begin{array}{l}\text { EHEA (European } \\
\text { Higher } \\
\text { Education Area) }\end{array}$} & $\begin{array}{l}\text { Europe } e^{23} \\
\left(2008^{24}\right)\end{array}$ & 2,041 & 879 & 2,219 & 1,948 & 7,087 \\
\hline & $\begin{array}{l}\text { Russia } \\
\left(2011^{25}\right)\end{array}$ & 2,220 & 1,856 & 2,479 & 2,414 & 8,969 \\
\hline LATIN AMERICA & $\begin{array}{l}\text { Latin America }{ }^{26} \\
\left(2005 \& 2012^{27}\right)\end{array}$ & 5,453 & 2,278 & 11,215 & 8,462 & 27,408 \\
\hline AFRICA & $\begin{array}{l}\text { Africa }^{28} \\
\left(2012 \& 2015^{29}\right)\end{array}$ & 1,813 & 1,311 & 2,183 & 1,790 & 7,107 \\
\hline
\end{tabular}

${ }^{23}$ The study included data from Austria, Belgium, Bulgaria, Croatia, Czech Republic, Denmark, Estonia, Finland, France, Germany, Greece, Hungary, Iceland, Ireland, Italy, Kosovo, Latvia, Lithuania, Malta, the Netherlands, Norway, Poland, Portugal, Republic of Macedonia, Romania, Serbia, Slovakia, Spain, Sweden, Switzerland, United Kingdom and Ukraine.

${ }^{24}$ For the complete study, see Beneitone and Bartolomé, "Global generic competences", 303-334.

${ }^{25}$ For the complete study, see Demchuk, Dyukarev, Karavaeva, Beneitone, González and Wagenaar, Towards Comparability of Higher Education Programmes".

${ }^{26}$ The studies included data from Argentina, Bolivia, Brazil, Chile, Colombia, Costa Rica, Cuba, Ecuador, El Salvador, Guatemala, Honduras, Mexico, Nicaragua, Panama, Paraguay, Peru, Uruguay and Venezuela.,

27 Two consultations were conducted in Latin America (2005 and 2012), with the 2005 list used verbatim in 2012 to collect data from stakeholders from additional Subject Areas. For more information, see Beneitone, Esquetini, González, Marty Maleta, Siufi and Wagenaar, Reflections on and Outlook for.

${ }^{28}$ The studies included data from Algeria, Benin, Botswana, Burkina Faso, Burundi, Cabo Verde, Cameroon, Democratic Republic of Congo, Côte d'Ivoire, Djibouti, Egypt, Ethiopia, Eritrea, Gabon, Gambia, Ghana, Kenya, Lesotho, Libya, Madagascar, Malawi, Mauritania, Mauritius, Morocco, Mozambique, Namibia, Nigeria, Rwanda, Senegal, Somalia, South Africa, South Sudan, Sudan, Tanzania, Tunisia, Uganda, Zambia and Zimbabwe.

${ }^{29}$ Two consultations were conducted in Africa (2012 and 2015) - the 2012 list was used again in 2015 to collect data from stakeholders from additional Subject Areas. For more information, see Awono Onana, Bandele Oyewole, Teferra, Beneitone, González and Wagenaar, Tuning and Harmonisation. 


\begin{tabular}{|c|c|c|c|c|c|c|}
\hline \multirow[t]{2}{*}{ Region } & \multirow[t]{2}{*}{ Study } & \multicolumn{5}{|c|}{$\begin{array}{l}\text { Number of respondents } \\
\text { (Academics - AA; Employers - EE; } \\
\text { Students - SS; Graduates - GG) }\end{array}$} \\
\hline & & AA & $\mathrm{EE}$ & SS & GG & Total \\
\hline \multirow{4}{*}{ ASIA } & $\begin{array}{l}\text { Central Asia }{ }^{30} \\
\left(2013^{31}\right)\end{array}$ & 3,562 & 1,226 & 4,766 & 1,634 & 11,188 \\
\hline & $\begin{array}{l}\text { China } \\
\left(2015^{32}\right)\end{array}$ & 307 & 482 & 474 & 485 & 1,748 \\
\hline & $\begin{array}{l}\text { South East Asia }{ }^{33} \\
\left(2017^{34}\right)\end{array}$ & 961 & 837 & 1,835 & 1,105 & 4,738 \\
\hline & $\begin{array}{l}\text { India } \\
\left(2018^{35}\right)\end{array}$ & 666 & 518 & 1,036 & 639 & 2,859 \\
\hline
\end{tabular}

Total: 103 countries; 71,094 respondents (17,023 Academics; 9,387 Employers; 26,207 Students; \& 18,477 Graduates).

Note: The left-most column indicates the region of the study (four continents represented). The second column shows specific studies and years of consultations, while the next five columns indicate the numbers of respondents - by category.

\section{Analysis of the global competences}

This section introduces the main results analysed in terms of the different regional and stakeholder groups' perceptions of the importance and achievement of the 11 global competences. Table 2 (below) summarized the results of the eight consultations in relation to each competence in terms of Importance (IMP) and Achievement $(\mathrm{ACH})$. It shows the rating given by the different stakeholders (Academics; Employers; Students; Graduates) and refers to the means for each competence on the 1 to 4 scale (1 - none, 2 - weak, 3 - considerable, 4 strong). Each competence was rated by the four stakeholder groups in terms of importance and achievement, so there are two results for each competence.

${ }^{30}$ The study included data from Kazakhstan, Kyrgyzstan, Tajikistan, Turkmenistan and Uzbekistan.

${ }^{31}$ For the complete study, see Isaacs, Najmitdinov, and Tasbolat. TUCAHEA.

${ }^{32}$ For the complete study, see Wagenaar, Gilpin and Beneitone, Tuning in China.

33 The study included data from Cambodia, Indonesia, Malaysia, Myanmar, Philippines, Thailand and Vietnam.

${ }^{34}$ For the complete study, see Jugar and Teda Ena, Reference Points.

35 For the complete study, see Tuning India Project 2018, accessed 17 October 2020, https://tuningindia.org/wp-content/uploads/T-India-2GM-Booklet-web.pdf. 
In terms of analysis, two aspects must be considered. First, a general overview of the average of each of the global competences helps us have a clear picture of the levels of two main variables, importance and achievement; and second, the gap between both variables introduces more elements for reflection. In order to proceed with the first step of the analysis, we need to take into account that the data collected in the surveys in the eight Tuning studies has a hierarchical structure, in the sense that individuals are nested in universities, and universities are nested in countries, forming a hierarchical structure. A multilevel approach ${ }^{36}$ has been taken here, as the data, due to this clustering effect, are not fully independent from each other and the results cannot be considered as completely random. To cope with this hierarchically structured data, an intra-class correlation needed to be calculated to check whether the differences between the aggregate units were high enough, and, therefore, to use the multilevel method for this purpose.

All the calculations of the data at university and country level were derived using this method as it takes into account, and controls for, the structure of data clustering. An additional advantage is that multilevel models allow the simultaneous appreciation of the difference at the individual respondent level and at the aggregate (university, subject area) level.

Once the clustering effect in the sample had been neutralized for comparison purposes, the mean scores for every global competence were computed in terms of the importance of the competence for the respondent, and in terms of the level of achievement the respondents believed had been reached for this particular competence in their context. The results of each individual Tuning study were shown in a comparative perspective in Table 2, in relation to the two main variables and the means. More detailed information about standard deviation and other more specific and concrete statistical data can be found in each of the eight Tuning studies separately.

A relevant aspect to stress is that Table 2 introduces a second level of analysis, which is the gap between the two variables (importance and achievement). For each competence, in relation to the perception of each stakeholder in each study, the gap that exists can be inferred. This gap is a central element that nourishes the whole reflection on global competences, their level of importance and the distance perceived by different stakeholders in different contexts, in terms of achievement. Table 2 allows to visualize the means of values assigned to both variables, but not directly the gap. This requires a much more detailed analysis that will be presented in the next

${ }^{36}$ Anthony S. Bryk and Stephen W. Raudenbusch, Hierarchical Linear Models: Applications and Data Analysis Methods (Sage: Newbury Park, CA, 1992). 


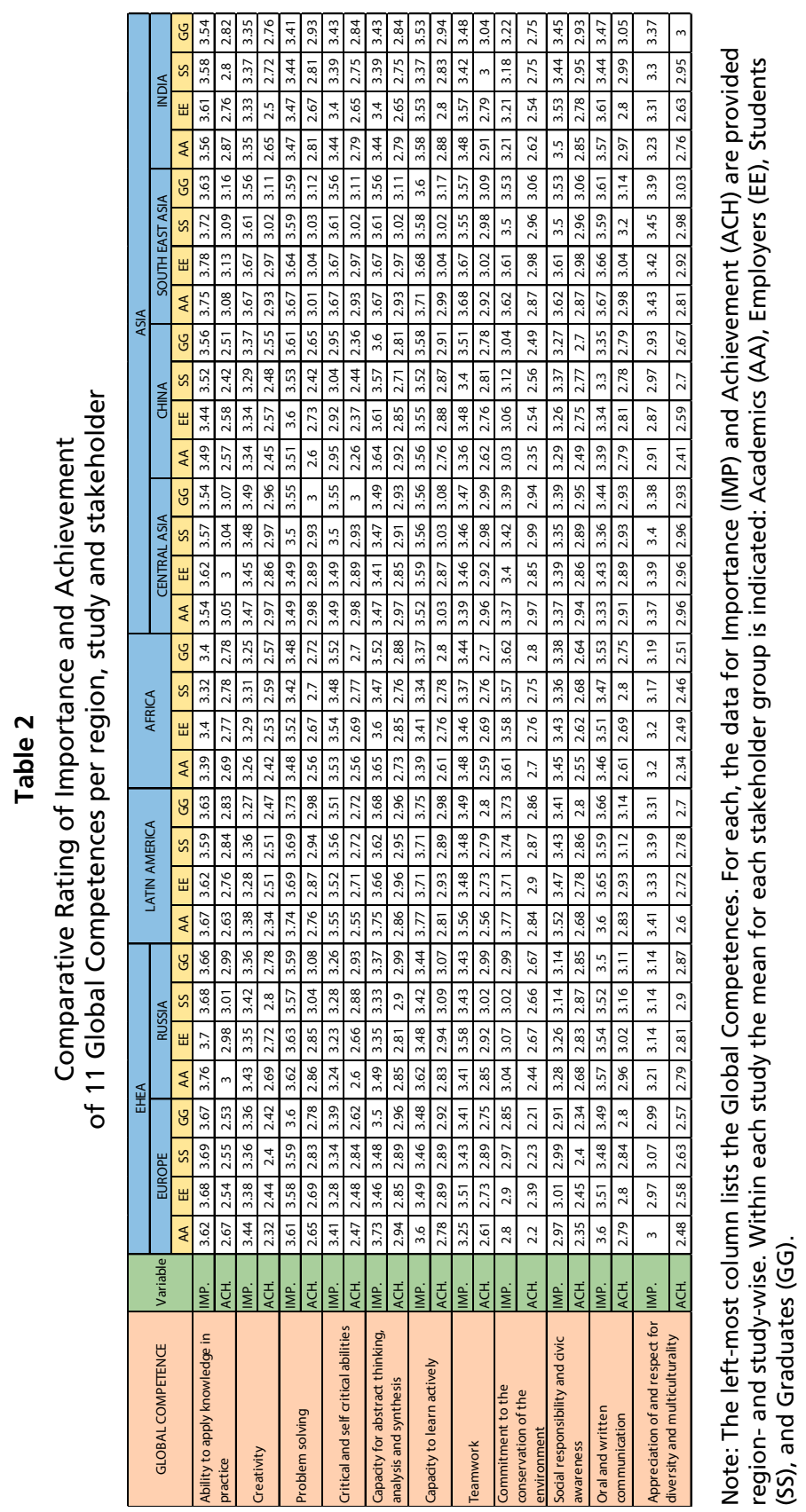

Tuning Journal for Higher Education 
eleven sub-sections that introduce one global competence after another and bring together the outputs of the meta-study, pointing out similarities and differences in competence ratings at the level of regions (EHEA, Latin America, Africa and Asia), zones/studies (see 'Study' column of Table 1) and stakeholder groups. The graphics (1 to 11) display the findings for each global competence across studies and regions.

Both Table 2 and Graphics 1-11 show that the mean for achievement is in all cases lower than the mean for importance: there is a gap between the desired and the actual level of competence development. This gap between the two variables/means is a crucial factor to consider, and such a gap is of greater concern when the competence in question is rated as a highly important, as all the global competence are. Therefore, each sub-section below looks first at the perceived importance of a given global competence, and next at the gap between its perceived importance and achievement.

\section{III.1. Ability to apply knowledge in practice}

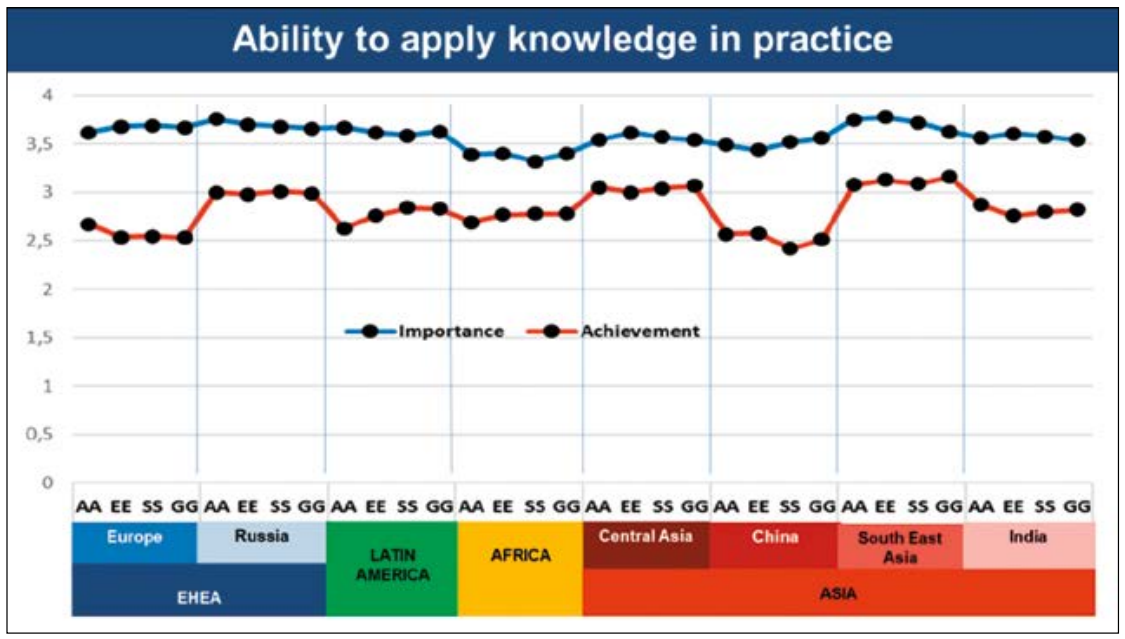

\section{Graphic 1}

Importance and Achievement Ratings for the 'Ability to apply knowledge in practice' competence across regions, studies and stakeholders

'Ability to apply knowledge in practice' is the competence perceived as the most important of the 11 global competences analysed in this meta-study. 
It was rated among the top 5 most important in most of the eight studies and by almost all stakeholders. An exception to this clear global trend is Africa, where it was rated among the last three in order of importance by all four stakeholders.

At global level, there does not appear to exist any clear pattern in terms of the stakeholder groups who tend to value this competence most or least. Employers indicate valuing it more often than any other stakeholder group, while Graduates most often give this competence a lower rating,

In terms of gap, and in comparison with the other 10 global competences, 'Ability to apply knowledge in practice' shows the largest gap values between importance and achievement in the 8 studies. Europe is the zone and EHEA the region that report the greatest gaps (1.09 for Europe and 0.89 for EHEA), while Central Asia is the zone and Africa is the region where the smallest gaps were reported ( 0.53 for Central Asia and 0.62 for Africa). It is interesting to stress that in Europe, when analysing the values given to the 11 global competences, 'Ability to apply knowledge in practice' appears as the most important, but also the one that shows the greatest gap from the levels of achievement. On the other hand, in Africa, this competence is perceived to be among the 3 least important global competences, but shows the smallest gap in this regional study.

\section{III.2. Creativity}

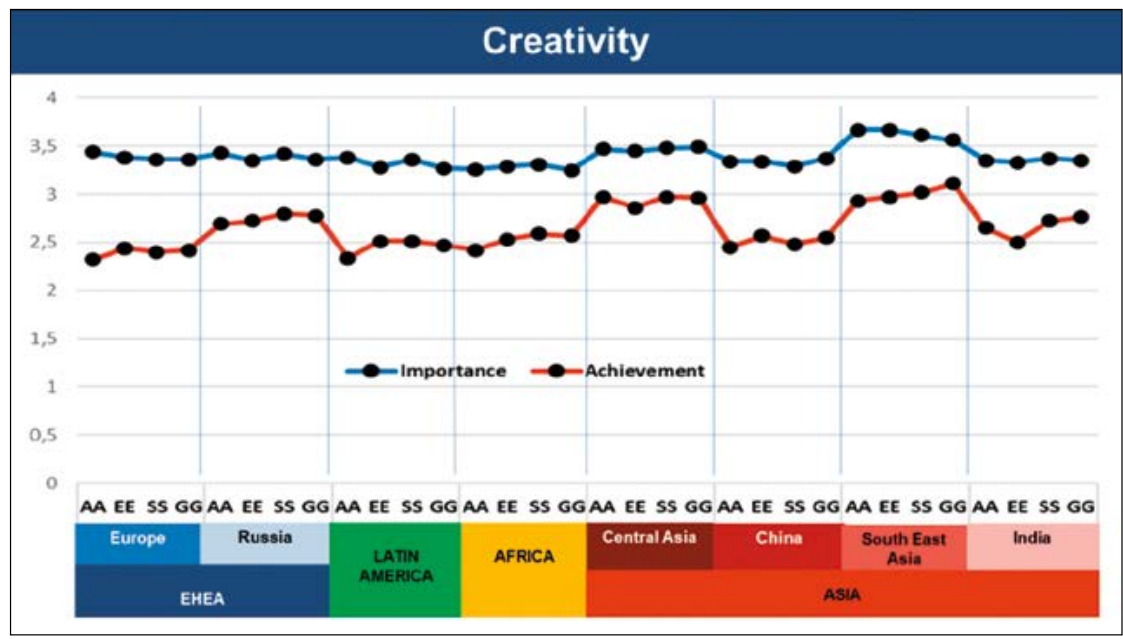

Graphic 2

Importance and Achievement Ratings for the 'Creativity' competence across regions, studies and stakeholders 
If we analyse each of the 8 studies individually, 'Creativity' does not appear among the five (or even six) most important competences in any zone/ region and occupies, rather, an intermediate position for the four stakeholders in almost all the studies, with the exception of Latin America and Africa, where it is considered the least important of the 11 global competences. When comparing the eight studies, and in terms of a trend in stakeholder evaluation, in four of the studies it is Academics who value it the most and Graduates the least (in Europe, Russia, Latin America and South-East Asia). Asia as a region and South-East Asia as a zone value this competence the most, while Africa and Latin America are at the opposite extreme. Academics and Employers in South-East Asia give this competence the highest rating (3.67) and Graduates in Africa - with the lowest (3.25).

In terms of the perceived gap, 'Creativity' is the second of the 11 global competences with the widest gap. When analysing the eight studies individually, in four of them (Europe, Russia, China and India) it is perceived as the competence with the biggest gap compared to the other 10 global competences. Academics are the most concerned: in six studies they identified the biggest gap. When looking at the eight studies comparatively in relation to 'Creativity', Latin America is the region with the widest gap. EHEA comes second, but if we look at Europe, the gap reported is even bigger than in Latin America (and Academics in Europe are the group who sees the biggest gap - 1.12). Central Asia reported the smallest gap, which led to Asian region on the whole featuring the lowest gap.

Comparing 'Creativity' with 'Ability to apply knowledge in practice', it is interesting to stress that both are the competences with the largest gaps in all the studies. An interesting difference to highlight is that there is no clear pattern between the most important competence and the one with the largest gap. For example, in Latin America, 'Creativity' appears as the least important with one of the three largest gaps with respect to the 11 global competences, while 'Ability to apply knowledge in practice' is among the three most important and also one with the largest gap. This means that it is not possible to defend a statement that says the greater the importance, the greater the gap with the perception of achievement.

\section{III.3. Problem Solving}

'Problem solving' is the competence perceived as the second most important of the 11 global competences analysed in this meta-study. It was rated among the top five most important in six of the studies and by almost all 


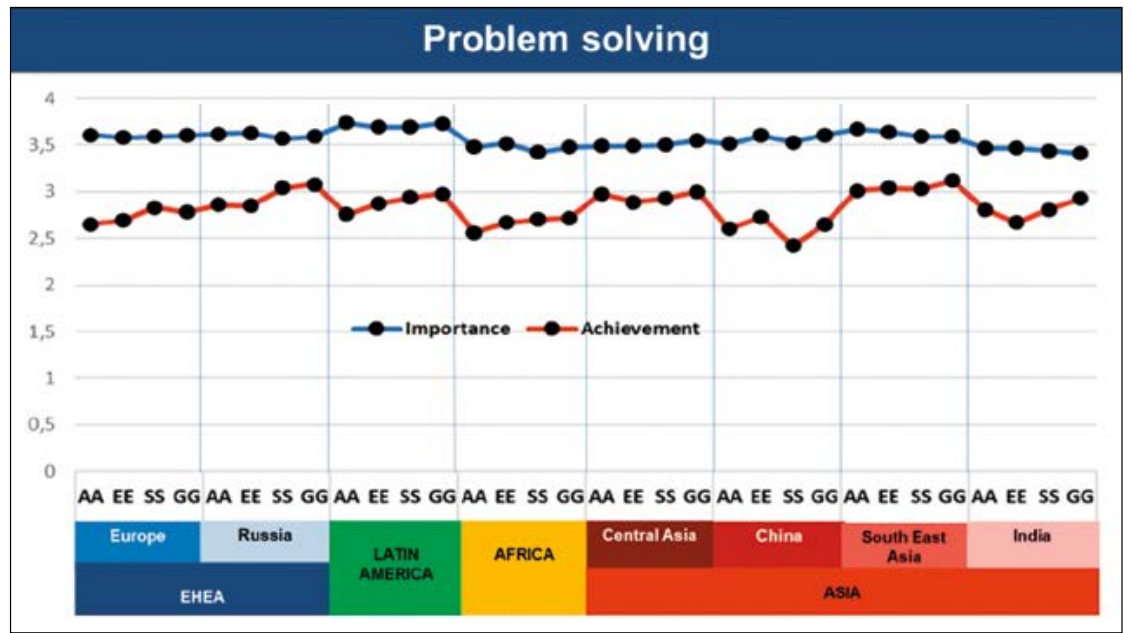

\section{Graphic 3}

Importance and Achievement Ratings for the 'Problem solving' competence across regions, studies and stakeholders

stakeholders, and even in the other two studies (India and South East Asia) some of the stakeholders (Students in both studies and Graduates in South East Asia) also rated it among the top five in terms of level of importance.

Academics tend to value this competence more than Graduates or Students, with the exceptions of Central Asia and China. Graduates, in turn, give it more importance than Students in six studies and three regions, with Asia being the exception. Latin American respondents value this competence the most, while Africa as a region and India as a zone feature the lowest average importance ratings.

In terms of the difference between importance and achievement, Employers report a bigger gap than Students or Graduates (with the exception of China), and Academics are more concerned than Students and Graduates in all the regions but for China and Central Asia. Furthermore, the gap reported by Academics is the biggest in two regions (Latin America and Africa) and three studies (Europe, Latin America and Africa), while in further three, those most concerned with achievement are Employers (Russia, Central Asia and India). Graduates, in contrast, are the most satisfied in three studies (Russia, South-East Asia and India) and share this lesser level of concern with Students in Latin America. The region most satisfied with the 'Problem solving' competence development is Asia, with Central Asia in 
particular being the study with the smallest gap reported. The region that reported the highest gap is Latin America, although the average gap reported is even higher in China, if we look at the level of a single study. Across all studies and stakeholder groups, the range of the gap between perceived importance and achievement is wider than for many other global competences, sharing this specific characteristic with the other two explained above: 'Ability to apply knowledge in practice' and 'Creativity'.

\section{III.4. Critical and self-critical abilities}

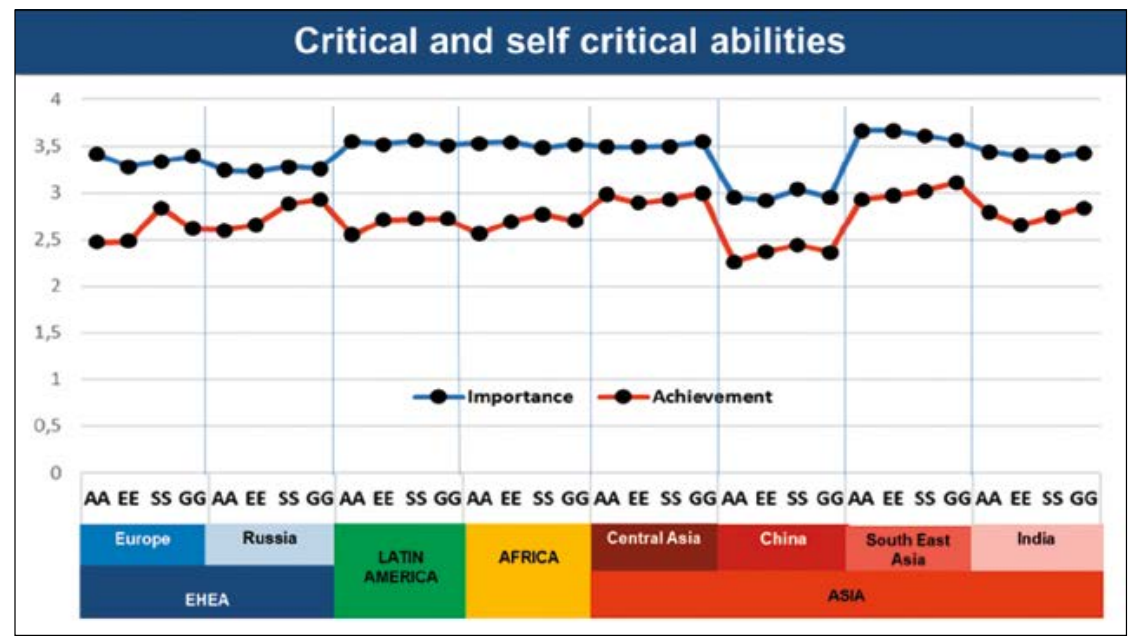

\section{Graphic 4}

Importance and Achievement Ratings for the 'Critical and self-critical abilities' competence across regions, studies and stakeholders

There is a coincidence in two studies (Africa and Central Asia) where all stakeholders value 'Critical and self-critical abilities' among the four most important of the 11 global competences. In China, on the contract, the four groups rated 'Critical and self-critical abilities' as one of the least important in comparison with the others global competences (10th position out of 11).

In terms of comparison of the level of importance among the stakeholders in the meta-study, Academics give it the highest importance compared to the other three groups in three studies; Employers do the opposite in four of the studies. There are, however, also studies where Employers value 'Critical and 
self-critical abilities' more than any other stakeholder group (Africa and South-East Asia) and one study where Students and Graduates (not Academics) are the group to give it the highest importance. Latin America is the region and South-East Asia the zone that value this competence the most. The lowest importance was given in EHEA as a region and China as a study/zone.

As for the gap, Academics reported the biggest gap in six studies (except for Central Asia and India), while Graduates reported the smallest gaps in four studies and the second-smallest gap in the other four. Asia is the region with the lowest perceived gap, while at the level of a single study this was so in Russia. Latin America is the region (and study/zone) in which the average gap reported was the highest.

\section{III.5. Capacity for abstract thinking, analysis and synthesis}

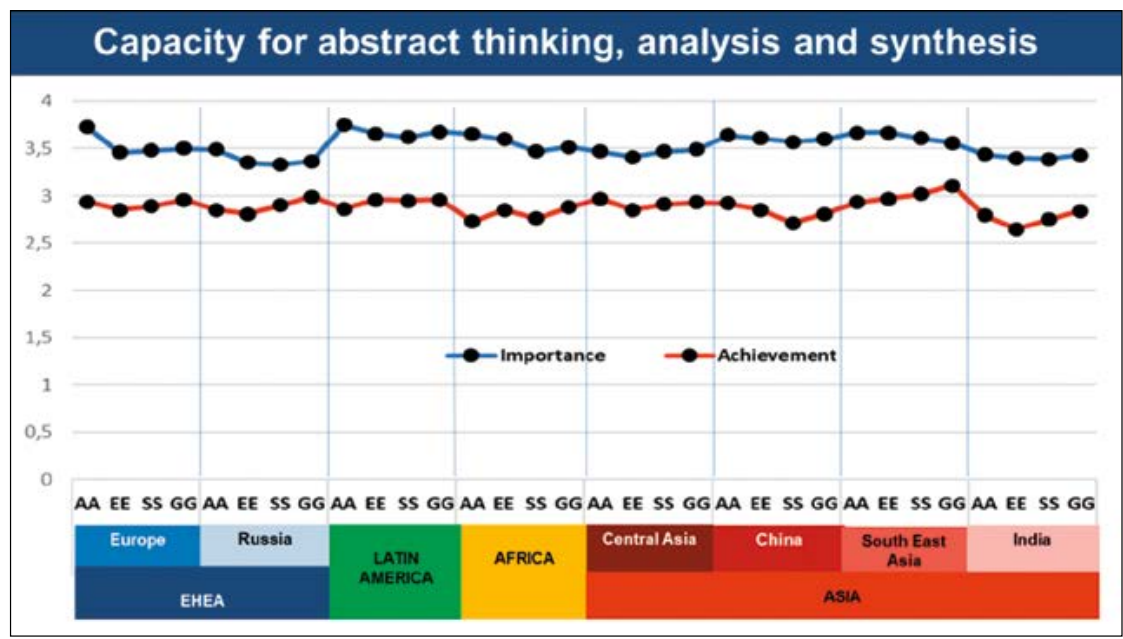

Graphic 5

Importance and Achievement Ratings for the 'Capacity for abstract thinking, analysis and synthesis' competence across regions, studies and stakeholders

In three studies (Latin America, Africa and China) all stakeholders value 'Capacity for abstract thinking, analysis and synthesis'among the 4 most important out of the 11 global competences. There are four other studies where some of the stakeholders consider this competence among the five most important, while in India, all four groups rate it among the four least important. 
In relation to the perception of importance from the perspective of the stakeholders, there seems to be clear patterns across regions. Academics most often value 'Capacity for abstract thinking, analysis and synthesis' the most (in seven studies) and Students the least (in five studies). The region that values this competence the least is EHEA, with Russia as the zone giving it the lowest average rating. On the other hand, Latin America rated 'Capacity for abstract thinking, analysis and synthesis' the highest, with Academics in Latin America being 'the champions' of this competence (3.75).

In terms of the gap, Graduates most often report the smallest gap (the least gap reported in five studies), while Academics tend to report the highest gap (in four studies). The study that reports the biggest gap is China, while the region with the lowest perceived gap is EHEA.

\section{III.6. Capacity to learn actively}

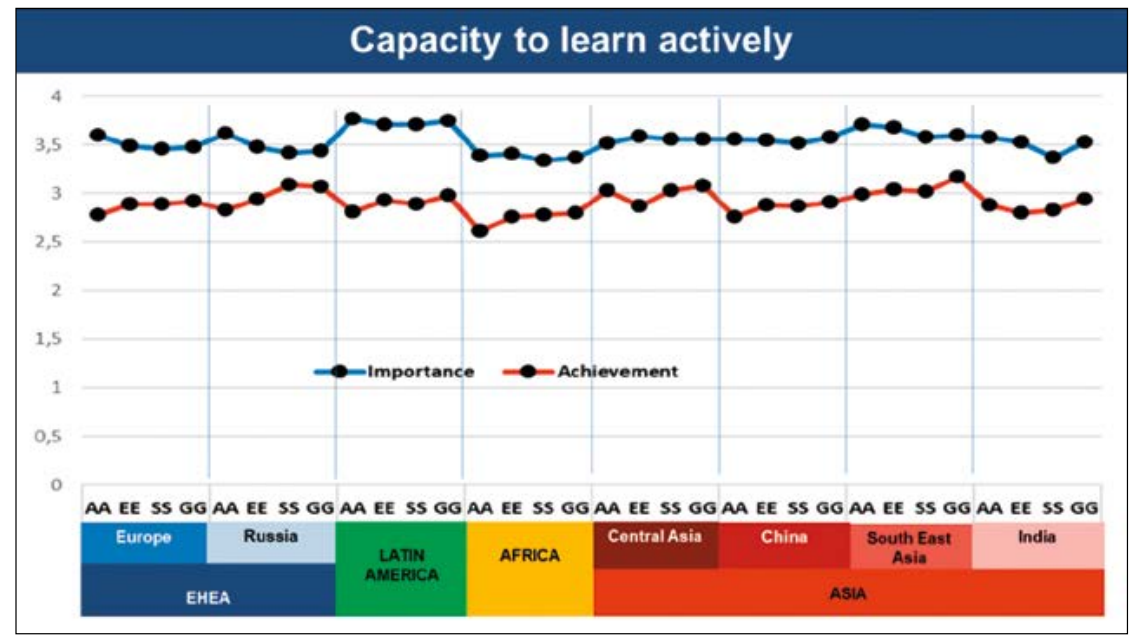

\section{Graphic 6}

Importance and Achievement Ratings for the 'Capacity to learn actively' competence across regions, studies and stakeholders

As with 'Ability to apply knowledge in practice' and 'Problem solving', 'Capacity to learn actively' is a competence perceived as one of the most important out of the 11 global competences analysed in this meta-study. It was rated among the top 5 most important by all stakeholder groups in five 
studies, and by some of the stakeholder groups (Academics, Employers and Graduates) in others (India and South East Asia). The case of Africa is an exception, because all African stakeholders rated 'Capacity to learn actively' among the four least important out of the 11 global competences.

If we compare the perception of the different stakeholder across the regions, Academics most often value 'Capacity to learn actively' most (in five studies) and Students tend to value it least (in seven studies). Except for Central Asia, Graduates everywhere value this competence higher than Students. Latin America values 'Capacity to learn actively' the most (with Academics being the 'champions' - 3.77).

In terms of the perceived gap, Academics are the most concerned. In six studies they identified a bigger gap than any other stakeholder group. Students appear less aware of the gap, which might be partly related to their tendency to give 'Capacity to learn actively' somewhat lesser attention.

Latin America as a region reported the widest gap (Academics being the most concerned), while Russia reported the smallest gap (with Students being the least concerned). This led to EHEA on the whole featuring the lowest gap compared to the other three regions.

\section{III.7. Teamwork}

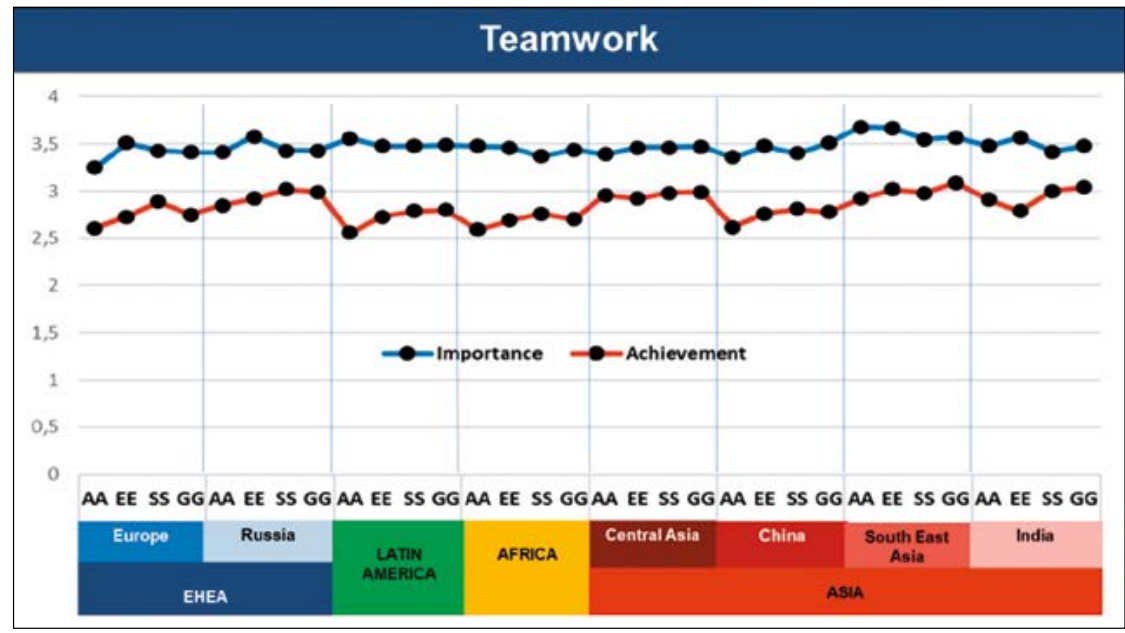

Graphic 7

Importance and Achievement Ratings for the 'Teamwork' competence across regions, studies and stakeholders 
In terms of importance, Students in all the studies value 'Teamwork' less than Graduates and, except Latin America, less than Employers. Academics, in turn, value 'Teamwork' the least in four studies and value it the most in three others. The region where 'Teamwork' is most valued is Latin America, although South-East Asia as a zone values this competence even more highly. The region that values 'Teamwork' the least is EHEA, with Europe as the zone giving it the average lowest rating (although still 3.4 out of 4). Across all stakeholders and studies, Academics in South-East Asia valued 'Teamwork' the highest, and Academics in Europe, the lowest.

In terms of the gap, Students most often report the smallest gap, while Employers and Academics tend to report the highest (Academic in four studies and Employers in the other four). Except for China, Employers everywhere appear more concerned with the level of 'Teamwork' development than Graduates. Latin America reports the biggest gap, Asia and EHEA, the lowest. Finally, Students in Russia see the smallest gap in achievement, while Academics in Latin America rate it the highest.

\section{III.8. Commitment to the conservation of the environment}

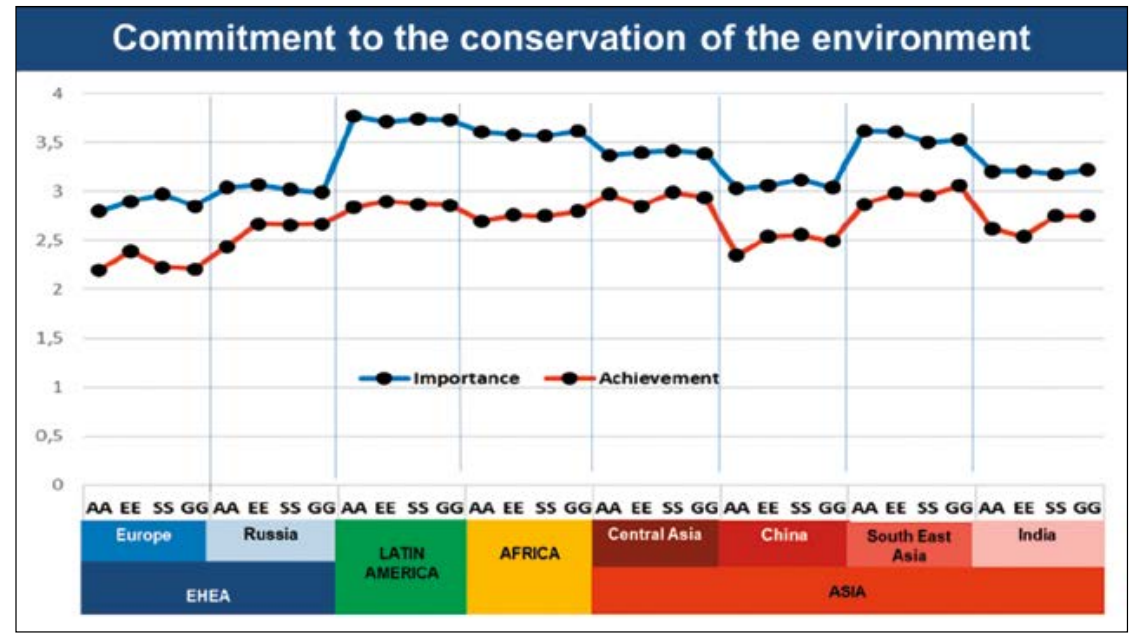

\section{Graphic 8}

Importance and Achievement Ratings for the 'Commitment to the conservation of the environment' competence across regions, studies and stakeholders 
In terms of importance, it can be observed that there are six studies that consider 'Commitment to the conservation of the environment' among the 3 least important global competences for all stakeholders compared to the rest of the competences. On the other hand, in Latin America and Africa, all stakeholders rate 'Commitment to the conservation of the environment' among the 3 most important competences.

Focusing on how the stakeholders rate this competence comparatively across the eight studies, Graduates and Students are the groups that most often value 'Commitment to the conservation of the environment' the highest of the four stakeholder groups and Academics and Employers are those who tend to value it least. At the level of regions, Latin America has the highest average (with Academics valuing it most at 3.77) and EHEA, the lowest (with Academics in Europe ascribing it the lowest importance - 2.80).

In terms of the gap between importance and achievement, Academics were the most concerned. In six studies they identified a bigger gap in 'Commitment to the conservation of the environment' competence development than any other stakeholder group. Employers appear less aware of the gap, which might be partly related to their tendency to give this competence somewhat less attention compared to other stakeholder groups.

Latin America and Africa reported the widest gap between importance and achievement for 'Commitment to the conservation of the environment'. It is interesting to note that, as mentioned above, this competence is at the top of the importance list for all stakeholders in both regions.

\section{III.9. Social responsibility and civic awareness}

'Social responsibility and civic awareness' is considered among the least important global competences in seven individual studies for all stakeholders. Only in India did all stakeholders rate it as one of the 5 most important global competences. In relation to the perception of the different stakeholders across the regions and zones, Academics value 'Social responsibility and civic awareness' most in four studies (Russia, Latin America, Africa and South-East Asia), while Students value it the least in five studies (Russia, Africa, Central Asia, South-East Asia and India). Latin America is the region where 'Social responsibility and civic awareness' is valued the most, although South-East Asia as a zone values it even higher. The region that values this competence the least is EHEA (with average for Europe being even below $3-2.97)$. 


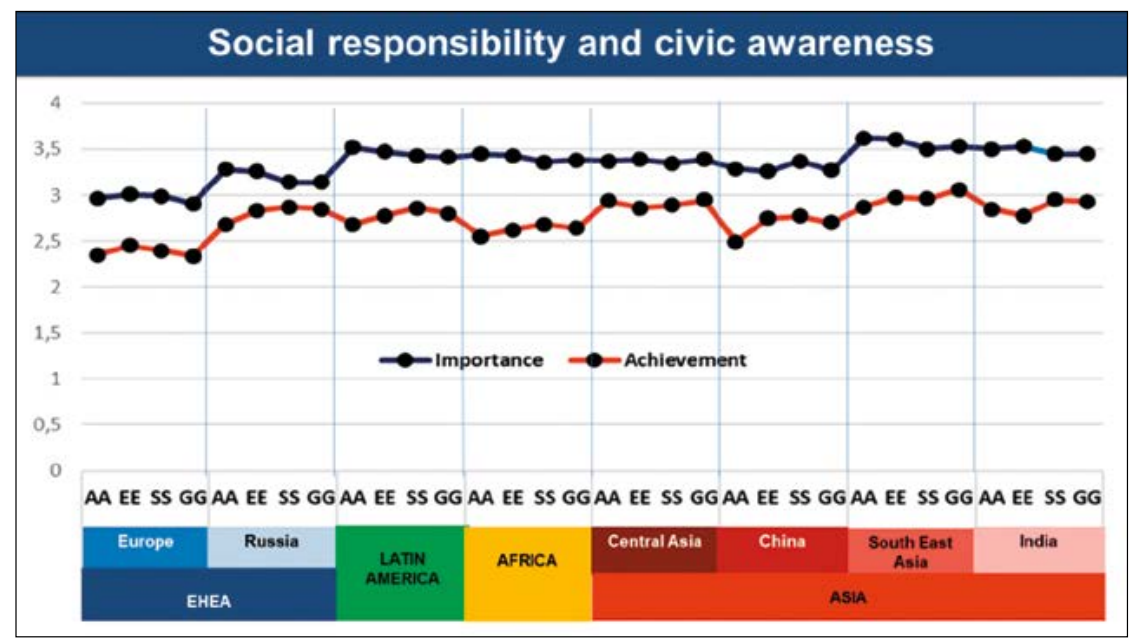

\section{Graphic 9}

Importance and Achievement Ratings for the 'Social responsibility and civic awareness' competence across regions, studies and stakeholders

As for the gap between importance and achievement, there is a clear pattern for almost all studies: Academics report the biggest gap (except for Central Asia and India), with the biggest one reported in Africa. Students in four studies report the smallest gap (Russia, Latin America, Africa and India), with the gap reported in Russia being the smallest.

At the level of zones/regions, Africa is the region with the greatest perceived gap and EHEA - with the smallest. Interestingly, EHEA region gave 'Social responsibility and civic awareness' the lowest level of importance, but also reported the smallest gap between desired and actual level of achievement. This implies that even though the competence was not perceived as being of highest importance in the region, stakeholders believe it to be well developed by students by the end of their HE studies.

\section{III.10. Oral and written communication}

In terms of importance, it can be observed that Employers in all regions value 'Oral and written communication' more than Students. Furthermore, Students tend to see this competence as less important compared to Graduates (with the exception of Russia). In two regions - Latin America and Africa - 
as well as in Central Asia zone, Graduates value 'Oral and written communication' the most. At the level of zones and regions, Latin America is the region which values this competence the most and so is South-East Asia as a zone. Asia, as a whole, is the region that values 'Oral and written communication' less than all the others. Within Asia, China has the lowest average in perceived importance (not only compared to the other Asian studies, but across all the eight studies). Finally, Academics in South-East Asia ascribed the highest value to 'Oral and written communication' (3.67), while Students in China did the opposite (3.30).

As for the gap between desired and actual achievement, in three regions (EHEA, Latin America and Africa) and six studies (adding China and SouthEast Asia), Academics report the highest difference, while Students report the lowest. In the other two studies - Central Asia and India, Employers report the biggest gap. Additionally, five studies (Europe, Russia, Latin America, Africa and South-East Asia) reveal the same pattern: Academics are concerned with the situation the most, Employers come second, Graduates third and Students the last. Furthermore, in all studies except India, Graduates see a bigger gap than Students, while Employers in all the studies report a bigger gap than Graduates and - with the exception of China - a bigger gap than Students as well. The region that reported the largest gap for 'Oral and

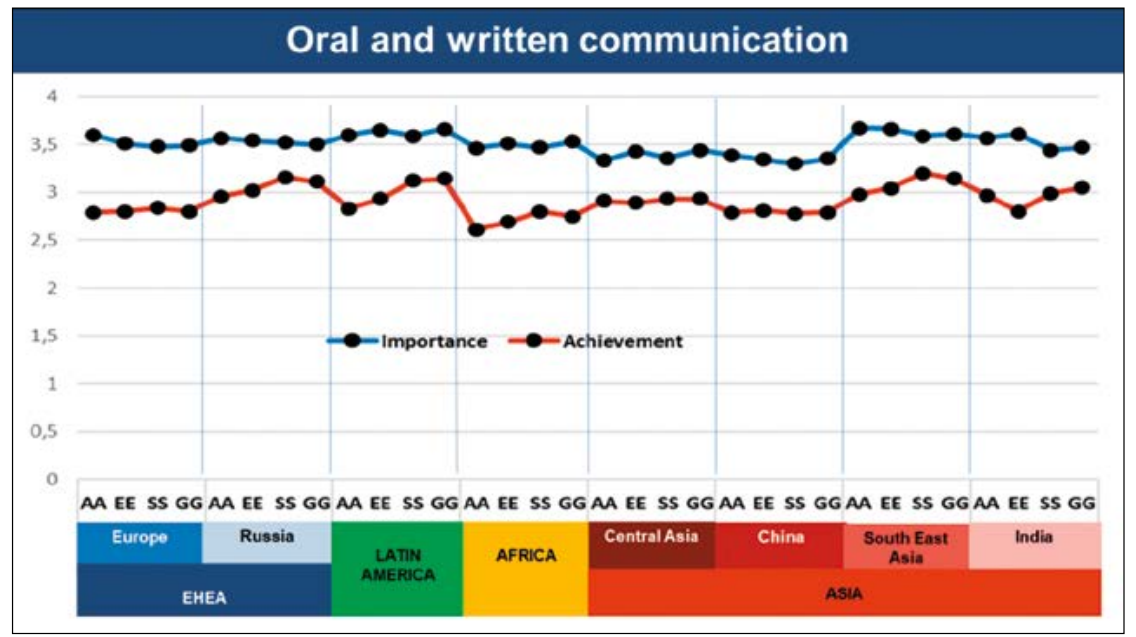

Graphic 10

Importance and Achievement Ratings for the 'Oral and written communication' competence across regions, studies and stakeholders 
written communication' was Africa (0.78), while the lowest gap was reported in Russia as a zone (0.47) and Asia as a region (0.53).

\section{III.11. Appreciation of and respect for diversity and multiculturality}

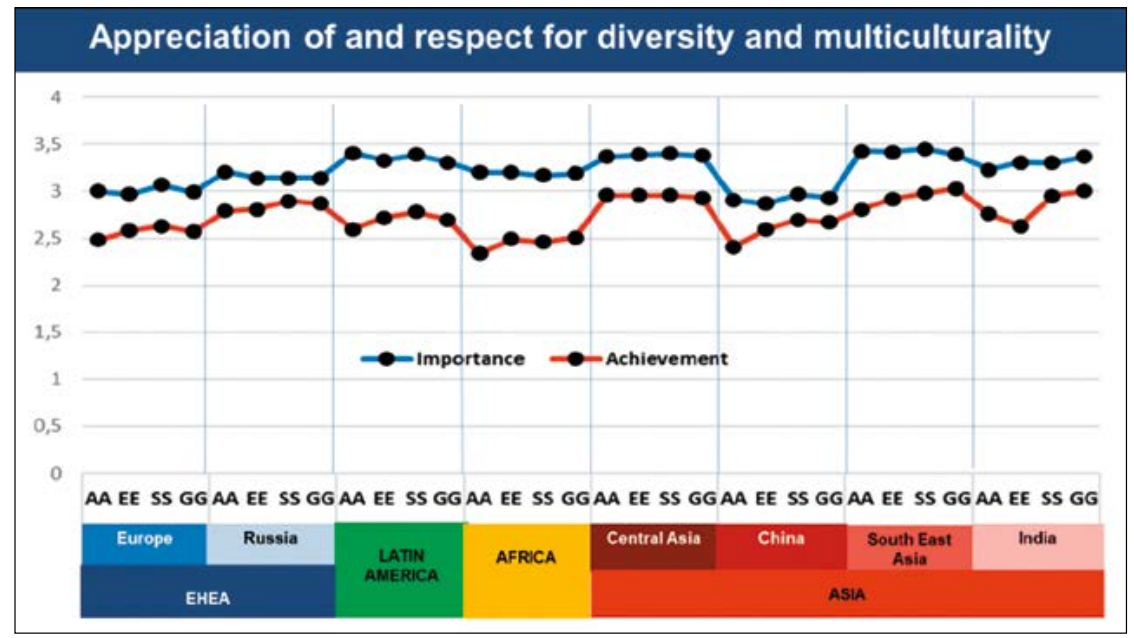

Graphic 11

Importance and Achievement Ratings for the 'Appreciation

of and respect for diversity and multiculturality' competence across regions, studies and stakeholders

'Appreciation of and respect for diversity and multiculturality' is considered one of the least important competences across the eight studies and from the perspective of all the stakeholders in comparison with the other 10 global competences. Latin America is the region where this competence is rated highest across all the stakeholder groups (3.36), although Students in South-East Asia value it even higher (3.45). China as a zone/study and EHEA as a region are at the opposite end, with perceived importance there being the smallest across the four stakeholder groups (although above 2.90 and 3.00 respectively).

As for the gap between perceived importance and achievement, Academics reported the biggest gap in six studies (except for Central Asia and India), while Students reported the smallest gaps in four of the studies, and the secondsmallest in three more. EHEA is the region where the gap observed across the 
stakeholder groups is the lowest ( 0.37 ; and even lower for Russia as a single study - 0.31). Africa is the region with the highest average gap reported for 'Appreciation of and respect for diversity and multiculturality' (0.74). Finally, Academics in Africa reported the highest gap (0.86), while Students in Russia were the group who perceived the smallest gap (0.24).

\section{Conclusions}

One of the main contributions of this comparative meta-study is additional, and stronger, evidence to confirm the importance of the 11 global competences - competences that were considered key elements of the desired graduate profile regardless of the area of studies in 103 countries. Apart from the fact that these competences appear in all the studies and regions, their importance is also consistently rated above 3 (out of 4). In fact, only in four of these competences did some stakeholder groups rate a competence below 3 , but never below 2.80 . This finding can clearly contribute to the current discussion on the internationalization of the curriculum and of which competences can be considered as 'strong candidates' to be seen as global. This means that by ensuring that students develop these 11 competences to a higher level, any HE programme could, at least partly, be meeting the goal of preparing globally-competent graduates.

It has been observed that there are differences that are visualized in the comparative analysis of each of the 11 global competences in the regions and countries. Here both the level of importance and the gap between the importance and the level of achievement provide very interesting elements for reflection. Variations are observed in terms of regions, but also in terms of the perception of the different stakeholder groups. For example, in the data related to importance, there are competences that show a similar behavior from the point of view of the four stakeholder groups within the same region (e.g. 'Appreciation of and respect for diversity and multiculturality' in Africa, China and South East Asia), and competences where certain stakeholders have a convergent perception, regardless of the region from which they respond (e.g. Students in all the studies valuing 'Teamwork' competence less than Graduates).

When importance and achievement data are compared across the four continents, in six of the eight studies, it is the Academics who clearly perceive the greatest gap between the level of importance and the level of achievement in all the 11 global competences, in comparison with the rest of the stakeholders. Only in Central Asia and India, the biggest differences are 
identified by Employers. Regarding the smallest gaps, the trend is not as strong as in the previous cases, although there is a prevalence of Students and Graduates reporting achievement to be very close to importance for the 11 global competences.

When comparing the 11 global competences, it is the 'Appreciation of and respect for diversity and multiculturality' that presents the smallest gap in almost all studies, and 'Ability to apply knowledge in practice' and 'Creativity' are the ones for which the greatest difference between importance and achievement have been reported in almost all regions. The graphic below summarizes the mean of gap (for the four stakeholders) among regions per global competence.

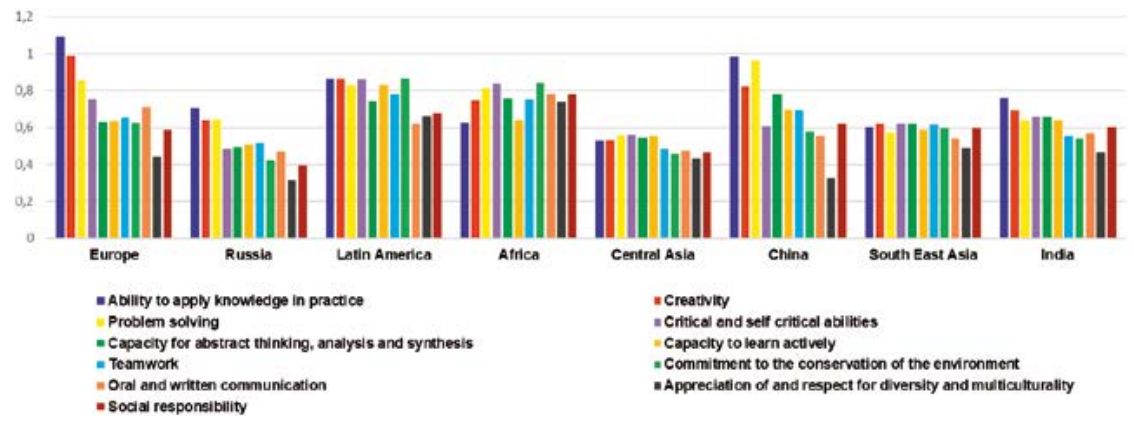

\section{Graphic 12}

Comparative gap of each Global Competence by study and region

It is interesting to highlight that Latin America and Africa show the largest and more balanced gaps in almost all of the 11 global competences in comparison with the other regions and studies. On the other hand, and in general terms, Central Asia and Russia seem to be the zones where the gaps in the 11 global competences are the smallest. As it was stressed in the particular analysis of some of the global competences, there are some studies which show a very wide gap in comparison with the others. For example, in a comparative analysis of the 11 global competences, Europe shows largest gap for 'Ability to apply knowledge in practice' and 'Creativity' in the present the meta-study. Furthermore, Latin America has the widest difference between the level of importance and the level of achievement in the eight studies for 'Teamwork', 'Commitment to the conservation of the environment', 'Capacity to learn actively' and 'Critical and self-critical 
abilities'. Africa shows the widest gap in comparison with the other regions and zones in relation to "Capacity for abstract thinking, analysis and synthesis', 'Social responsibility and civic awareness', 'Oral and written communication' and 'Appreciation of and respect for diversity and multiculturality'. Finally, China has the largest gap for 'Problem solving' in comparison with the other seven studies.

Each competence in itself, and all of them as a whole, seen across regions, open a space for reflection regarding what is lacking in order to bring graduates closer to achieving the desired level of the competence(s) in order to close the gap between the importance and the perceived achievement. This is one of the questions the present meta-study would like to raise by way of suggesting possible future lines of analysis and interpretation.

Two more future research questions are directly linked to the limitations of the present meta-study: some world regions are not covered in this paper and the data analysed were not collected at the same time. In relation to the first aspect, no comparable date has so far been collected in North America (USA and Canada) or Oceania. Collecting data from these regions can assist in confirming whether what is displayed here as potentially global is, indeed, global. The second possible future development involves a new consultation conducted synchronously in all the regions of the world. This will allow us to compare results and perceptions world-wide, without the possible interference of the time factor.

To conclude, focusing of these 11 global competences in a degree programme might be highly instrumental in approaching curriculum internationalization. The research presented, however, has stressed how relevant and necessary it is for HE Institutions to ensure the presence of global competences, not only in curriculum design, but - much more importantly - in implementation: to ensure that graduates indeed develop the global competences. This article shows that there is some reflection and further efforts to be made by HE Institutions in order to close the gap between the desired and actual achievement of these global competences. The meta-study has also highlighted that it is critical to engage different stakeholder groups in reaching this goal and meeting the expectations of the society. All of them are part of a global society and have something to say and contribute to the solution.

\section{Bibliography}

Arvanitakis, James, and David Hornsby. Universities, the citizen scholar and the future of higher education. Basingstoke: Palgrave Macmillan, 2016. 
Awono Onana, Charles, Olusola Bandele Oyewole, Damtew Teferra, Pablo Beneitone, Julia González, and Robert Wagenaar. Tuning and Harmonisation of Higher Education: The African Experience. Bilbao: University of Deusto, 2014. Beneitone, Pablo, César Esquetini, Julia González, Maida Marty Maleta, Gabriela Siufi, and Robert Wagenaar. Reflections on and Outlook for Higher Education in Latin America. Bilbao: University of Deusto, 2007.

Beneitone, Pablo, and Edurne Bartolomé. "Global generic competences with local ownership: a comparative study from the perspective of graduates in four world regions." Tuning Journal for Higher Education 1, no. 2 (May 2014): 303-334. https://doi.org/10.18543/tjhe-1(2)-2014.

Borkovic, Shinead, Toula Nicolacopoulos, Dell Horey, and Tracy Fortune. "Students positioned as global citizens in Australian and New Zealand universities: A discourse analysis". Higher Education Research \& Development 39, no. 6 (2020): 1106-1121. https://doi: 10.1080/07294360.2020.1712677.

Bryk, Anthony S., and Stephen W. Raudenbusch. Hierarchical Linear Models: Applications and Data Analysis Methods. Sage: Newbury Park, CA, 1992

Clifford, Valerie and Martin Haigh. "Graduate attributes for global citizenship". In Moving towards internationalisation of the curriculum for global citizenship in higher education, edited by Valerie Clifford and Catherine Montgomery, 93118. Oxford: OCSLD, Oxford Brookes University, 2011.

Clifford, Valerie, and Catherine Montgomery. "Designing an internationationalised curriculum for higher education: embracing the local and the global citizen." Higher Education Research \& Development 36, no. 6 (2017): 1138-1151. https://doi.org/10.1080/07294360.2017.1296413.

Demchuk, Artur, Ivan Dyukarev, Evgeniya Karavaeva, Pablo Beneitone, Julia González, and Robert Wagenaar. Towards Comparability of Higher Education Programmes. Information Review. Bilbao: University of Deusto, 2013.

Hajkowicz, Stefan, Andrew Reeson, Lachlan Rudd, Alexandra Bratanova, Leonie Hodgers, Claire Mason, and Naomi Boughen. Tomorrow's digitally enabled workforce: Megatrends and scenarios for jobs and employment in Australia over the coming twenty years. Brisbane: CSIRO, 2016.

Isaacs, Anne Katherine, Ahahdon Najmitdinov, and Aimen Tasbolat. TUCAHEA Tuning Central Asia Towards a Central Asian Higher Education Area. Pisa: Dedalo edizione, 2016.

Jugar, Richard, and Ouda Teda Ena. Reference Points for the Design and Delivery of Degree Programmes in Teacher Education. Tuning South East Asia. Bilbao: University of Deusto, 2019.

Leask, Betty. Internationalizing the Curriculum. New York and London: Routledge, 2015.

Lilley, Kathleen, Michelle Barker, and Neil Harris. "Educating global citizens: a good 'idea' or an organisational practice?," Higher Education Research \& Development 34, no. 5 (2015): 957-971. doi: 10.1080/07294360.2015.1011089.

Oliver, Beverly, and Trina Jorre de St Jorre. "Graduate attributes for 2020 and beyond: recommendations for Australian higher education providers." Higher 
Education Research \& Development 37, no. 4 (2018): 821-836. doi: 10.1080/07294360.2018.1446415.

Sarkar, Mahbub, Tina Overton, Christopher D. Thompson, C., and Gerry Rayner.

"Academics' perspectives of the teaching and development of generic employability skills in science curricula." Higher Education Research \& Development 39, no. 2 (2020): 346-361. doi: 10.1080/07294360.2019.1664998.

Schech, Susanne, Maryanne Kelton, Colin Carati, and Verity Kingsmill. "Simulating the global workplace for graduate employability." Higher Education Research \& Development36,no.7(2017):1476-1489.doi:10.1080/07294360.2017.1325856.

Tuning India Project 2018. Accessed 17 October 2020. https://tuningindia.org/wpcontent/uploads/T-India-2GM-Booklet-web.pdf.

Wagenaar, Robert. Reform! TUNING the Modernisation Process of Higher Education in Europe. A Blueprint for Student-Centred Learning. Bilbao and Groningen, 2019.

Wagenaar, Robert, Arlene Gilpin, and Pablo Beneitone. Tuning in China. An EUChina Feasibility Study into the Modernisation of Higher Education. Bilbao: Universidad de Deusto, 2015.

\section{About the authors}

DR. PABLO BENEITONE (pbeneitone@unla.edu.ar) is Professor at the National University of Lanús (Argentina) with a degree in International Relations, a Master in International Cooperation and a PhD in Social Sciences. During most of his professional and academic career since 1994, he has been general coordinator of international programmes and projects on academic mobility, regional convergence and international university cooperation (Erasmus +, ALFA, TEMPUS, Erasmus Mundus, etc.) in different countries and regions. He is the author of several scientific publications related to current issues in higher education, as well as the director of research on academic mobility, credit systems, global competences and learning outcomes, and the impact of these on the processes of curriculum internationalisation. He has been a speaker at various international university events in more than 50 countries, both in Europe, Asia, Africa and Latin America, related to internationalisation processes.

DR. MARIA YAROSH (m.yarosh@rug.nl) works at the International Tuning Academy at the University of Groningen, the Netherlands, as a researcher and faculty developer. She holds a $\mathrm{PhD}$ in Education awarded by the University of Deusto, Spain; and is an alumna of an Erasmus Mundus Masters in Lifelong Learning: Policy and Management (Institute of Education, University of London/UCL, UK). She has been working for the Tuning Academy since 2013 and has participated in a number of Tuning projects across the world (Africa, Asia, Europe \& Latin America). Her main research areas are intercultural competence development and faculty development associated with implementing competence-based student-centred approach in higher education contexts. 


\title{
A Comparative analysis of global competences within the framework of internationalized curricula
}

\author{
Pablo Beneitone and Maria Yarosh
}

doi: http://dx.doi.org/10.18543/tjhe-8(2)-2021pp25-53

\section{Copyright}

Copyright for this article is retained by the Publisher. It is an Open Access material that is free for full online access, download, storage, distribution, and or reuse in any medium only for noncommercial purposes and in compliance with any applicable copyright legislation, without prior permission from the Publisher or the author(s). In any case, proper acknowledgement of the original publication source must be made and any changes to the original work must be indicated clearly and in a manner that does not suggest the author's and or Publisher's endorsement whatsoever. Any other use of its content in any medium or format, now known or developed in the future, requires prior written permission of the copyright holder. 